\title{
HISTÓRIA E ENSINO DURANTE A DITADURA MILITAR NO BRASIL: \\ UMA REFLEXÃO A PARTIR DAS MEMÓRIAS DE UM PROFESSOR (1954-1982)
}

\author{
HISTORY AND TEACHING DURING THE MILITARY DICTATORSHIP IN \\ BRAZIL:
}

A REFLECTION FROM THE MEMORIES OF AN ADVENTIST TEACHER

(1954-1982)

\author{
Janaina Silva Xavier ${ }^{1}$ \\ Jonathan Contrera Avila² \\ Pamela Silveira da Silva ${ }^{3}$
}

Willian Batista dos Santos Junior ${ }^{4}$

\begin{abstract}
RESUMO: Este texto expõe um Trabalho de Conclusão de Curso (TCC) de Licenciatura em História, do Centro Universitário Adventista de São Paulo, campus Engenheiro Coelho, que teve como objeto de discussão as memórias dos anos de docência de um professor de História, Adventista do Sétimo Dia, durante o período da Ditadura Militar no Brasil (1964-1985). O objetivo do estudo foi contribuir com novas perspectivas a respeito do ensino de História no período ditatorial brasileiro e analisar os discursos envolvidos nas narrativas dos "velhos" sobre seu passado, explorando a História Oral como metodologia de construção histórica. O professor entrevistado com questionários semiestruturados, Luíz Contrera, de 91 anos, descreveu seu processo formativo e seus anos de docência em diferentes escolas no estado de São Paulo e na capital, sem assumir uma postura ativista. Como fundamentação teórica foram escolhidos autores dos campos da memória e da historiografia, a fim de problematizar as narrativas do depoente, entre eles, Ferreira Junior e Bittar (2006), Lira (2010), Prado (2014), Bosi (1994), Pollock (1989), Pollak (1992), Portelli (2006) e Thompson (2002). O estudo concluiu que os relatos do professor Luíz foram em grande parte condizentes com a História do período, mas revelaram importantes aspectos da realidade docente que servem para reflexão sobre as diversas camadas envolvidas na questão.
\end{abstract}

Palavras-chave: Memória. Ensino de história. Ditadura militar. Brasil.

\footnotetext{
${ }^{1}$ Licenciada em Artes Visuais, Especialista em Patrimônio Cultural e Conservação de Artefatos, Mestre em Memória Social e Patrimônio Cultural (UFPEL), Mestre em Museologia (USP), Doutoranda em Artes Visuais (UNICAMP). Professora e Museóloga do Centro Universitário Adventista de São Paulo (UNASP EC). E-mail: janaina.xavier@unasp.edu.br

2 Licenciado em História pelo Centro Universitário Adventista de São Paulo. Professor no Centro Universitário Adventista de São Paulo (UNASP HT). Email: avila.95.j@hotmail.com

${ }^{3}$ Licenciada em História pelo Centro Universitário Adventista de São Paulo. E-mail: pamela.silveira@unasp.edu.br

4 Licenciado em História pelo Centro Universitário Adventista de São Paulo. Professor na Escola Adventista de Jundiaí. E-mail: willian_batista@outlook.com.br
} 


\begin{abstract}
This text presents an undergraduate thesis towards a Degree in History at the Adventist University of São Paulo in Engenheiro Coelho. The object of discussion was the teaching memories of a Seventh-day Adventist history teacher during the military dictatorship in Brazil (1964-1985). The objective of the study was to contribute with new perspectives regarding the teaching of History during the Brazilian military dictatorship and to analyze the discourses involved in the narrative of "elders" about their past, exploring oral history as a methodology of historical construction. The teacher interviewed with semi-structured questionnaires was Luiz Contrera, 91 years old. He described his formative process and years of teaching in different schools in the state of Sao Paulo and in the capital, without taking an activist stance. As theoretical basis, authors from the fields of memory and historiography were chosen to problematize the narratives of the interviewee, among them are, Ferreira Junior e Bittar (2006), Lira (2010), Prado (2014), Bosi (1994), Pollock (1989), Pollak (1992), Portelli (2006) e Thompson (2002). The study concluded that teacher Luiz's reports were largely consistent with the history of the period. However, his reports revealed important aspects of the teaching reality that serve for reflection on the various layers involved in the issue.
\end{abstract}

Keywords: Memory. Teaching of history. Military dictatorship. Brazil.

\title{
Introdução
}

Este artigo apresenta os resultados de uma investigação científica que teve como tema o ensino da História durante o regime militar no Brasil (1964-1985) e mais particularmente como objeto de discussão as memórias e narrativas de um professor sobre as políticas educacionais e a sua própria prática pedagógica nesse contexto.

A ditadura militar é uma fase recente da História que repercutiu de forma significativa e impactante na sociedade brasileira e a Educação esteve entre os setores que sofreram as maiores intervenções, alterando suas concepções, formas de organização, planejamento, coordenação e controle, permitindo diferentes abordagens e reflexões, e é nesse quadro que essa pesquisa se insere.

Soma-se a isso, a possibilidade de colher depoimentos de pessoas que viveram essa realidade o que torna esse estudo mais enriquecedor $e$ mais legítimo. A memória e as narrativas orais possuem uma relação natural com a História. Tendo sido difundidas antes da escrita, durante o Período Clássico, e em outros momentos da História, essa tradição perdeu força e prestígio com o surgimento do Positivismo, no começo do século 
XIX. Foi somente a partir da metade do século XX, que a História Oral se estabeleceu como prática reconhecida, através dos debates sobre a memória e a História, promovidos pelos historiadores da Escola de Annales $^{5}$. Na contemporaneidade, a memória, na forma de História Oral, tem ocupado o primeiro plano dentre muitos estudos inovadores sobre a História Social e Cultural, reconceituando e refazendo construções históricas, até mesmo da História diplomática e política.

De acordo com essa metodologia, a entrevista é a maneira de se obter dados específicos do momento histórico trabalhado, sendo, portanto, a fonte básica para a formulação dessa História Oral, buscando compreender o passado e dar voz aos esquecidos, os excluídos e os derrotados, entre outros tantos personagens olvidados nos documentos escritos.

Diante dessa realidade, essa pesquisa foi norteada pelos seguintes questionamentos: quais as percepções de um professor sobre o sistema educacional e a sua prática docente no período da ditadura militar no Brasil? Em que medida suas lembranças e discursos se aproximam ou se afastam da história oficial? Podem as narrativas orais trazer novos meandros para a questão?

O objetivo do estudo foi refletir sobre o ensino da História durante a ditadura militar a partir das memórias e narrativas de um professor que atuou nesse período, num exercício historiográfico que emprega a História Oral como fonte de pesquisa. Tal investigação se justifica por questionar as complexas relações imbricadas nos processos educacionais, a partir da visão humana de um de seus importantes atores sociais - o professor - que esteve imerso em uma realidade relacionada a essa fase turbulenta da História brasileira.

A metodologia empregada utilizou a análise de livros didáticos de História, Educação Moral e Cívica e Organização Social e Política Brasileira, publicados durante a ditadura militar e disponíveis na Biblioteca do UNASP

\footnotetext{
${ }^{5}$ A Escola dos Annales foi um movimento historiográfico surgido na França, durante a primeira metade do século XX. A historiografia passou por grandes modificações metodológicas através da incorporação de diferentes fontes de pesquisa, entre elas, a História Oral.
} 
EC, o exame das legislações que implantaram mudanças no sistema escolar (Lei Federal n 5.540, de 28 de novembro de 1968 e Lei Federal no 5.692, de 11 de agosto de 1971) e a reflexão teórica em textos que consideram como foi a Educação na época, entre eles Ferreira Jr. e Bittar (2006), Lira (2010) e Prado (2014). Também serviram de aporte conceitual as teorias de Bosi (1994), Pollock (1989), Pollak (1992), Portelli (2006) e Thompson (2002), que tratam a respeito do campo da memória e das narrativas dos idosos. Essas investigações prévias permitiram contextualizar, confirmar e compreender os depoimentos do professor Luíz Contrera, de 91 anos, com formação em Magistério e Estudos Sociais e que atuou na docência entre os anos de 1953 a 1982, no estado de São Paulo, pois as declarações não podem ser interpretadas como verdade absoluta apenas por se tratar de uma pessoa mais velha e que testemunhou os fatos, mas devem ser analisadas à luz dos conhecimentos de outros materiais para saber se as informações são confiáveis.

As declarações do professor, que durante as entrevistas revelaram uma postura não ativista contra o regime militar e fortemente influenciada por sua profissão de fé, foram colhidas através de questionários semiestruturados e conversas espontâneas na casa do docente, conforme as orientações de Tourtier-Bonazzi (2006). O vínculo com o depoente, sugerido pela autora, foi propiciado pela relação parental entre o professor Luíz e o pesquisador Jonathan Contrera Avila, seu neto. O artigo discute inicialmente os aspectos relacionados à ditadura e à Educação e, na sequência, são apresentadas a biografia do professor Luíz, suas origens e formação, suas experiências na docência e a influência de sua opção religiosa cristã nos seus comportamentos e discursos, seguidos das considerações finais.

\section{Ditadura e Educação}

Após o golpe que a democracia brasileira sofreu com a destituição do governo de João Goulart da presidência da república, em 1964, o regime instaurado, constituído por militares, tomou algumas atitudes para se 
consolidar no poder. Além do fechamento do Congresso Nacional e das Assembleias Legislativas estaduais, de prender, reprimir, censurar e torturar a população para que não se rebelasse contra o Executivo, uma das principais ações para garantir o controle da sociedade foi fazer profundas alterações no ensino para que, dessa forma, as próximas gerações fossem educadas de acordo com os interesses do poder vigente.

Ferreira Junior e Bittar (2006) afirmam que a escola foi um dos meios mais eficazes de difusão da ideologia que respaldou o regime militar. Para isso acontecer algumas reformas educacionais tiveram que ser instauradas, no sentido de afirmar claramente as doutrinas e princípios do governo, tornando a Educação mais funcional e em sentido oposto ao comunismo e às ideias de esquerda.

Durante o período da ditadura no Brasil pode-se destacar duas importantes mudanças no sistema educacional. A primeira delas foi realizada em 1968, com foco no cenário universitário e a outra, em 1971, que afetou principalmente o que hoje chamamos de Educação Básica. A Lei Federal $n^{\circ}$ 5.540, de 28 de novembro de 1968, fixou as normas de organização e funcionamento do Ensino Superior visando a manutenção da ordem, a repressão aos movimentos estudantis e minimizar as ondas de protestos pela falta de acesso à universidade. A legislação subordinou todas as instituições de ensino superior ao Conselho de Educação, aglutinou os estabelecimentos isolados, definiu que a escolha de reitores e diretores fosse feita pelo Governo Federal com mandatos de quatro anos, atribuiu aos reitores e diretores o dever de defender as normas e a disciplina, dispôs que a universidade deveria estimular a formação cívica, a consciência dos direitos e deveres do cidadão e profissional, criou o vestibular classificatório, eliminando os alunos excedentes e implantou cursos profissionais de curta duração, incluindo as licenciaturas, entre outras determinações.

Três anos depois foi aprovada outra reforma para a Educação brasileira de $1^{\circ}$ e $2^{\circ}$ graus (atuais Ensino Fundamental e Médio) pelo presidente Emílio Garrastazu Médici, através da Lei Federal n 5.692, de 11 de agosto de 1971. A legislação previu a unificação dos pequenos 
estabelecimentos de ensino, determinou a criação de um currículo comum e obrigatório a ser instituído pelo governo, deu ênfase na formação profissional e na iniciação para o trabalho e tornou obrigatória a inclusão da disciplina de Educação Moral e Cívica (EMC), além disso, as matérias de História e Geografia ficaram restritas ao $2^{\circ} \mathrm{grau}$, sendo substituídas pelos Estudos Sociais no $1^{0}$ grau. A lei também eliminou as disciplinas de Sociologia e Filosofia que, por serem consideradas de cunho socialista, instigavam o pensamento crítico. No pensamento de Vedana (1997, p. 54):

Introduzir as disciplinas sobre civismo significa impor a ideologia da ditadura, reforçada pela extinção da Filosofia e diminuição da carga horária de História e Geografia, que exerce a mesma função de diminuir o senso crítico e consciência política da situação.

Lira (2010) sugere que a Educação no decorrer do período militar não foi nada mais que uma peça num jogo de xadrez, onde o que estava valendo era a manutenção do poder sobre a nação, reprimindo os pensamentos dos cidadãos e eliminando possíveis resistências. Durante os anos do governo de ditadura, o Brasil teve seis ministros da Educação, sendo que nenhum deles tinha formação ou ligação com a área, o Ministério da Educação não passava, portanto, de um instrumento para confirmar o poder.

O ano de 1971 também foi marcado pelo início dos "Anos de Chumbo", período em que a repressão aos opositores ao governo ganhou uma força jamais vista no país. Aliado a isso, o famoso "Milagre Econômico", que teve seu auge entre 1970 e 1971, gerou um clima de euforia entre a classe média consumidora e a expectativa de que a nação atingiria a industrialização e o progresso. Com essa aparente escalada econômica nacional e os violentos mecanismos de controle social, o governo tinha mais força para fazer as mudanças que desejava.

De acordo com Prado (2014), após o ano de 1971, o ensino profissionalizante supostamente deveria se tornar obrigatório, ocasionando uma profunda mudança na estrutura escolar da época. Lira (2010, p. 11), por sua vez, afirma que "os eventos foram marcantes, indo desde a ênfase tecnicista nos currículos, a fusão da História e Geografia nos Estudos 
Sociais, a prisão e tortura de estudantes e professores, a expansão das escolas particulares".

Prado (2014) ainda menciona que até o ano de 1961 havia duas aulas semanais de História e duas de Geografia, tanto no ginásio quanto no colegial. Com a introdução das disciplinas de caráter nacionalista Organização Social e Política Brasileira (OSPB) implantada pelo Conselho Federal de Educação, em 1962, e de Educação Moral e Cívica (EMC), acrescentada na reforma de 1971 - houve uma redução nas aulas semanais de Estudos Sociais para o $1^{\circ}$ grau e de História e Geografia para o $2^{\circ}$ grau. Essa diminuição ocorreu tanto em conteúdo quanto no número de aulas.

Entretanto, o objetivo dessas novas disciplinas não foi plenamente alcançado. Na prática a OSPB tornou-se meramente mais uma aula semanal de História, muito provavelmente porque o professor estava habilitado a lecionar aulas nessa área, dessa forma ele usava o tempo para colocar em dia o conteúdo que mais lhe interessava. Além disso, com o passar dos anos, a EMC adquiriu apenas a função de difundir e explicar as comemorações cívicas do país (PRADO, 2014).

Fonseca (2007) relembra que o programa curricular imposto durante a ditadura militar instituía um ensino diretivo, que não propunha a crítica e que mostrava a História como uma sucessão linear de fatos significativos, onde a política e o militarismo eram exaltados, com destaque para os grandes nomes, ou seja, um currículo aonde o espírito positivista conduzia a História. Na visão de Plazza e Priori (2008, p. 11):

\begin{abstract}
A História passou a servir como justificadora do sistema governamental vigente, pois teve a sua estrutura de ensino voltada para atender as bases ideológicas dos militares obtendo respostas isoladas e totalmente descontextualizadas, impedindo assim uma reflexão mais crítica, o homem comum não era visto como um ser participante da construção histórica a qual estava inserido.
\end{abstract}

A disciplina de História buscava reproduzir as ideologias da classe social dominante que, por sua vez, acreditava que o progresso nacional estava diretamente ligado ao sucesso do capitalismo. Nesse processo, o professor acabava perdendo a liberdade de planejar as aulas, pois era obrigado a seguir o material didático rigorosamente. Prado (2014, p. 191) 
afirma que ao analisar os livros didáticos da época é possível perceber que eles "não permitem o diálogo com o leitor, porque carecem da capacidade de insinuar; não foram confeccionados para serem interrogados, nem para criarem interrogantes". A maioria das questões encontradas nos livros escolares do período tinha por finalidade apenas fazer o aluno decorar datas, cidades e nomes. Na ideologia desse modelo pedagógico:

[...] o elemento principal passa a ser a organização racional dos meios, ocupando o professor e o aluno posição secundária, relegados que são à condição de executores de um processo [...] a cargo de especialistas supostamente habilitados, neutros, objetivos, imparciais. A organização do processo converte-se na garantia da eficiência, compensando e corrigindo as deficiências do professor e maximizando os efeitos de sua intervenção (SAVIANI, 2010, p. 382).

Portanto, vê-se que o regime militar no Brasil agiu no controle da formação dos professores na universidade e, posteriormente, na sua atuação em sala de aula, organizando um sistema centralizado, tanto administrativa quanto pedagogicamente, que monopolizava o ensino, impondo a defesa e a exaltação do poder autoritário disfarçado de nacionalismo. Nesse contexto, temos a atuação de muitos educadores, vítimas desse aparelho estatal, que trabalhavam nas escolas como agentes do poder instituído, por vezes, reprimidos, censurados e coagidos, pouco capazes ou dispostos a subverter essa realidade. Passadas três décadas desse período, ouvir as narrativas desses professores pode descortinar novas camadas de interpretação desse momento da História, além de dar voz àqueles que por muito tempo tiveram que ficar calados, apenas reproduzindo os discursos impositivos dos dominadores.

\section{O professor Luíz: os primeiros anos e a vocação para o magistério (1926- 1957)}

Luíz Contrera é descendente de espanhóis, nasceu como último dos nove filhos do casal, no bairro do Brás, na cidade de São Paulo, em 16 de junho de 1926. Seu pai, que morreu quando Luíz tinha dois anos, era ferroviário na Estrada de Ferro Central do Brasil. Sua mãe se dedicou à 
Educação e cuidado dos filhos em casa e, com a morte do marido, passou a receber uma pensão da estrada de ferro.

Os irmãos de Luíz eram alfaiates e tinham sua oficina de costura em casa, enquanto as irmãs trabalhavam na indústria têxtil da família Matarazzo, no Brás. Desde pequeno, Luíz recebeu instruções de seus irmãos a respeito do trabalho e da economia do dinheiro, já aos onze anos de idade aprendeu a chulear calças em troca de uma pequena mesada e abriu uma caderneta de poupança no banco. O jovem teve uma influência muito presente da família no seu desenvolvimento. Sempre atentando para os princípios cristãos, assim como seus irmãos, não tinha o costume de beber nem de envolver-se em festas, embora alguns deles tivessem o hábito de fumar.

Sobre esse tempo, o professor de 91 anos afirma6: "dá saudade de São Paulo naquela época", e completa assegurando a respeito de suas origens: "eu descendo de uma família muito cristã e com muitas amizades". Segundo Bosi (1994, p. 22) "a conversa evocativa de um velho é sempre uma experiência profunda. Repassada de nostalgia $[\ldots]^{\prime \prime}$. Deste modo, ele considera a infância e a juventude como um período agradável na companhia da mãe e dos irmãos. Faz questão de afirmar seu valor, embora descenda de família humilde, eram cristãos e tinham reconhecimento social. Sobre esse ponto, Pollak (1992, p. 204) explica também que "[...] há uma ligação fenomenológica muito estreita entre a memória e o sentimento de identidade".

Algum tempo depois, enquanto cursava o ginásio, Luíz se interessou por ser ruralista e acabou ingressando na Escola Agrícola José Bonifácio, em Jaboticabal, estudando lá por cerca de um ano. Por ter sido a primeira vez que saiu de casa e sendo ainda muito jovem, não se adaptou e acabou voltando para morar com a mãe e os irmãos. Logo após o término do ginásio fez um concurso para trabalhar na Estrada de Ferro Santos-Jundiaí e conseguiu seu primeiro emprego como encarregado de supervisionar o

\footnotetext{
${ }^{6}$ Depoimento livre concedido aos pesquisadores em 25 e 26 de maio de 2017, na residência do entrevistado, em Tatuí, SP.
} 
despacho do café para o porto de Santos: "Mas eu não gostei muito, eu não fazia nada", avalia Luíz.

Por não se acostumar ao expediente monótono de seu cargo administrativo na estrada de ferro, Luíz buscava outras oportunidades, quando soube por um colega de trabalho que o Instituto de Educação Caetano de Campos estava oferecendo o Curso Normal para exercer o magistério (FIGURA 1).

Figura 1 - Instituto de Educação Caetano de Campos, em 1943. O edifício foi inaugurado em 1894, sediando além do curso Normal, os cursos de Letras, Filosofia, Geografia, História, Ciências Sociais e Pedagogia da Faculdade de Filosofia, Letras e Ciências (FFLC) da USP, a partir de 1938.

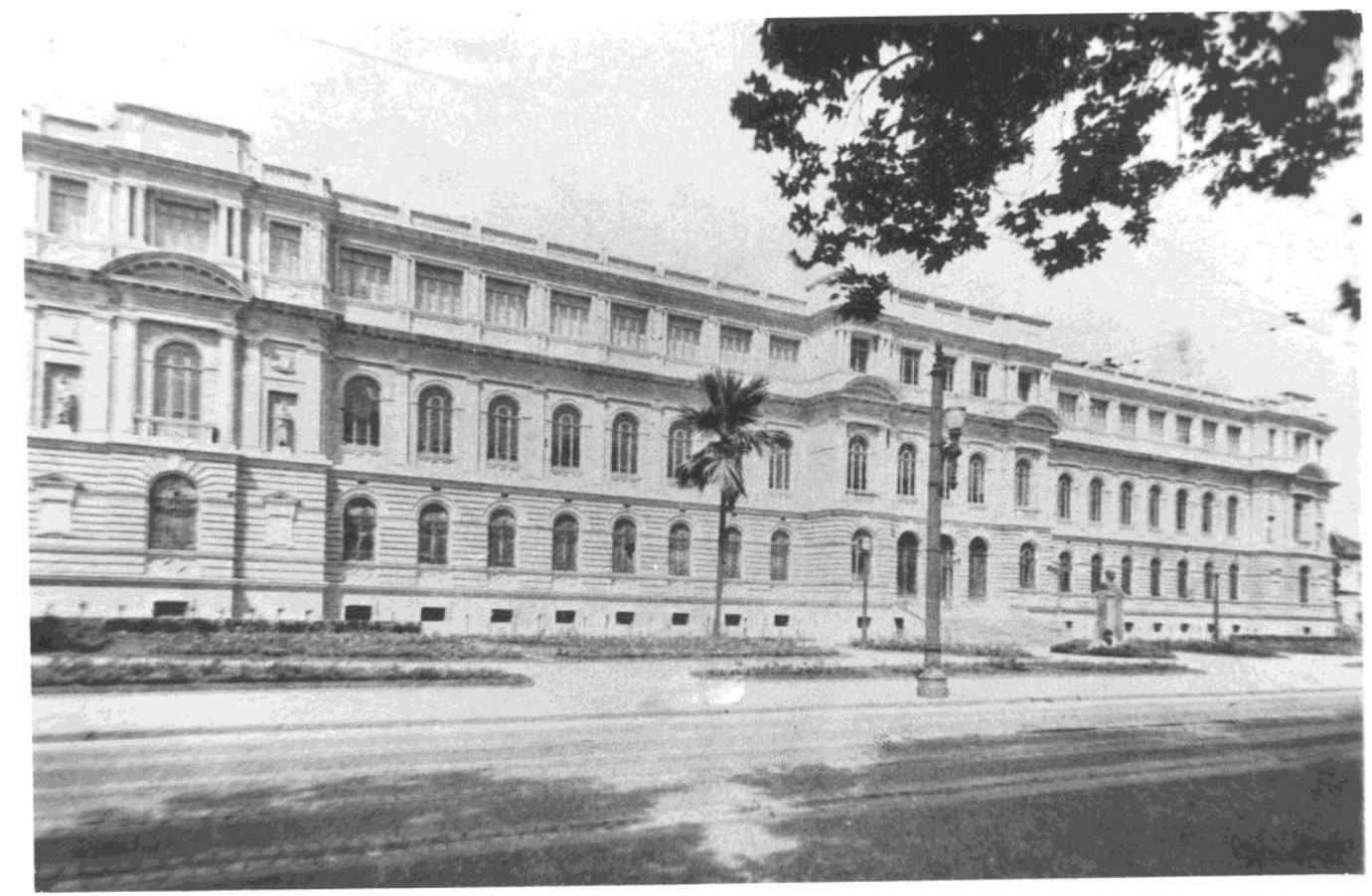

Fonte: USP (2017).

A Escola Caetano de Campos tinha grande destaque na época, sendo responsável pela formação de importantes personalidades brasileiras como Sérgio Buarque de Holanda, Francisco Matarazzo, Mário de Andrade, Oswald de Andrade, Cecília Meireles, entre outros. Embora Luíz nunca antes houvesse cogitado a ideia de ser professor, acabou se familiarizando com a 
Educação, ainda que este exercício profissional fosse predominantemente feminino na época, como se pode observar no retrato da turma de 1950, ano em que recebeu seu diploma (FIGURA 2).

Figura 2 - Formandos da Escola Estadual Caetano de Campos, SP, 1950. O professor Luíz encontra-se na última fila, quase ao centro, de terno branco, atrás da aluna com um chapéu grande e branco.

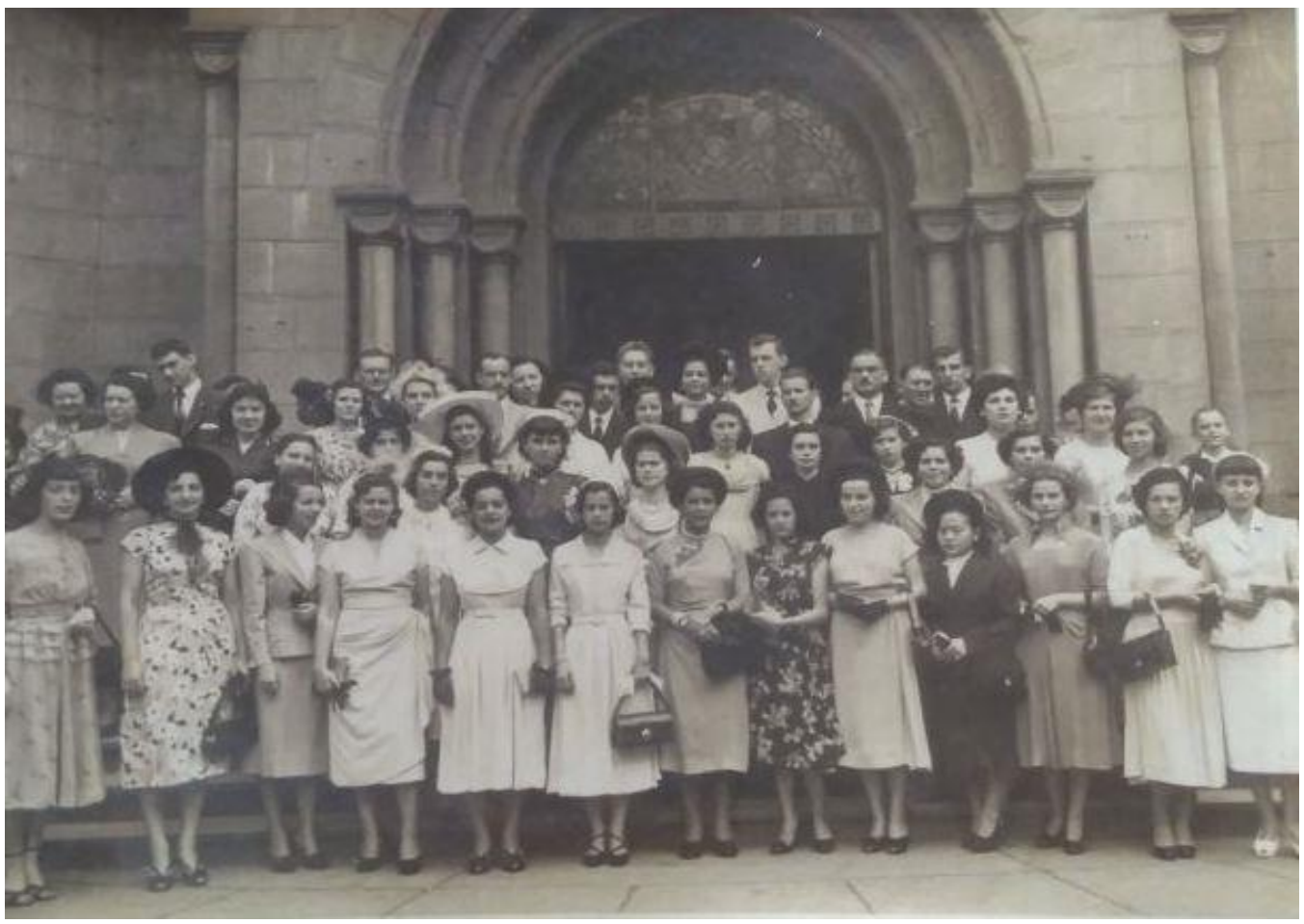

Fonte: Acervo do Entrevistado.

Segundo Guacira Lopes Louro (2015, p. 449) o interesse das mulheres de classe média pela Educação foi uma característica do Brasil nesse período:

Ao serem criadas as escolas normais, a pretensão era formar professores e professoras que pudessem atender a um esperado aumento na demanda escolar. Mas tal objetivo não foi alcançado exatamente como se imaginava: pouco a pouco, os relatórios iam indicando que, curiosamente, as escolas normais estavam recebendo e formando mais mulheres que homens. 
Ao recordar-se de sua formação o entrevistado destaca: "ah foi gostoso, muito gostoso!", e em seguida acrescenta "já dava o estágio ali, aí tinha que preparar uma aula com matérias e tudo". Essas lembranças da juventude, de acordo com Voldman (2006), expressam mecanismos complexos de construção do passado, onde frequentemente percebe-se um saudosismo em relação aos anos dourados da mocidade, desconsiderando, muitas vezes, as dificuldades e problemas enfrentados.

Logo após se formar, Luíz atuou como professor substituto no Grupo Escolar Frei Galvão, em São Paulo. Em pouco tempo prestou concurso e iniciou sua carreira como professor efetivo, em 1953, na Fazenda Nova América, em Assis, SP. A partir daí, lecionou em Adamantina, na Vila Jacuí, na Escola Estadual Zalina Rolim e, por fim, na Escola Amadeu Amaral, no bairro do Belém, em São Paulo, onde se aposentou, em 1982. Ao longo de sua trajetória, demonstrou interesse em uma formação continuada, mesmo antes de ingressar na Caetano de Campos já havia cursado taquigrafia, em 1944. Em 1953, se qualificou para o ensino de crianças excepcionais pela Sociedade Pestalozzi de São Paulo e, futuramente, em 1977, se formou como licenciado em Estudos Sociais pela Faculdade de Filosofia, Ciências e Letras Professor Carlos Pasquale. Durante a entrevista afirmou: "professor tem que fazer cursinhos, vira e mexe tem que fazer cursinhos". Essa postura demonstra o interesse do entrevistado por sua profissão, buscando qualificar-se para exercer seu ofício.

Prado (2014) comenta que durante este período, a graduação do professor era determinada por um currículo de disciplinas distintas observadas na prática do estágio supervisionado. Para quem desejasse se graduar em Estudos Sociais, em 1972, deveria cumprir, de forma obrigatória, estudos e estágios em História, Geografia, Ciências Sociais, Filosofia, Teoria Geral do Estado, OSPB, Estudos dos Problemas Brasileiros e Educação Física. Essa grade curricular formava um profissional com múltiplas competências, porém sem aprofundamento em nenhuma área do conhecimento. 
O ano de 1957 marcou o final dessa etapa da juventude e deu início à vida adulta de Luíz. Ele conheceu a Igreja Adventista do Sétimo Dia (IASD) e após receber estudos bíblicos de um membro da denominação, aceitou suas doutrinas e se converteu. Esta opção acabou marcando não apenas sua carreira profissional e sua ética de trabalho, mas, também, sua vida pessoal, pois foi na igreja que ele conheceu sua futura esposa, Marly, treze anos mais nova. Em 1959, oficializaram o matrimônio e deste tiveram dois filhos, Rebeca (1965) e Fábio (1967).

Analisar a experiência do professor Luiz como aluno do curso de magistério na Escola Caetano de Campos e, posteriormente, em sua atuação como docente em escolas públicas do estado de São Paulo, nos permite vislumbrar interlocuções com as perspectivas, os caminhos e os atores da Educação e do Ensino de História no Brasil durante o regime militar, a partir de reflexões humanas, políticas, sociais e religiosas.

\section{Ser professor de história na Ditadura}

Ao começar as narrativas sobre sua trajetória como professor, Luíz fala dos conteúdos que ensinava: "o descobrimento do Brasil, fundação de cidades, os governos, administração de prefeituras". A partir dessa fala, percebe-se o predomínio da História Política, de caráter obrigatório no ensino da época. Porém, curiosamente ele afirma: "Nada era influenciado pela política", o que revela uma interpretação pessoal controversa, que contraria os documentos e as pesquisas históricas do período.

Em sua análise, o professor vai além, afirmando que não houve grandes mudanças em relação ao material didático, os conteúdos das aulas e até mesmo a forma de se lecionar durante a transição e os anos que se estenderam à ditadura militar. Ao ser indagado sobre os livros didáticos, 0 professor Luíz afirma: "Eram livros práticos" [...] "Tinha que seguir o programa e graças a Deus sempre deu certo" [...] "Era tudo didático".

Apesar dessa fala do professor, percebemos que durante o regime militar os professores eram controlados e aqueles que manifestaram qualquer grau de oposição foram perseguidos, ameaçados, punidos e 
afastados. Era preciso cumprir rigorosamente o programa das disciplinas estabelecido pelo Estado. Havia a presença de militares nas escolas vigiando o desenvolvimento das atividades $e$ às vezes os próprios professores e funcionários faziam denúncias (PRADO, 2014). Nesse relato do professor Luíz é possível perceber que os traumas psicológicos desse cerceamento não foram apagados. Sua fala pode revelar o receio que sentia em não conseguir atender o cronograma imposto.

Sobre suas metodologias de ensino, o professor esclarece: "Tinha parte que eu escrevia, mas era mais falado" [...] "a maioria também decorava fácil e eu também decorava". Nota-se, então, que os procedimentos pedagógicos estavam centrados em fazer o aluno memorizar os conteúdos e do professor também era exigida essa competência. Apesar desse controle severo, em certo momento ele relembra uma prática mais inovadora: "eu fiz uma dramatização". Em seguida, conta que a encenação não foi bem aceita por um dos alunos, que reclamou para os pais e o caso foi levado à direção da escola.

Nessa experiência fracassada compreende-se que os professores não tinham autonomia de experimentar variantes em sala de aula, pois os próprios alunos estranhavam a proposta e se fizessem queixas aos pais e à direção da escola, o docente era repreendido. Segundo Prado (2014, p. 55), "o professor tinha a função de técnico organizador e os alunos recebiam, aprendiam e fixavam informações", ou seja, ele atuava sem liberdade de pensamento e ação.

Em sala de aula, Luíz adotava um discurso passivo: "nem se fazia debate político assim [...] passava o conteúdo para acalmar a situação". Mais uma vez seus temores transparecem ao revelar que assumia esse papel de mediador, receando que se despertasse insubmissão nos alunos, os estudantes poderiam sofrer perseguições. Com a introdução de EMC, Luíz passou a ministrar também essa disciplina: "eu gostava daquilo, para mim foi prático" [...] "eu sempre dei incentivo de obediência ao governo, mas dentro das normas cristãs".

Em outro momento ele expressa sua adequação às propostas ideológicas do governo: "incentivava para o estudo, não para anarquia". Ao 
avaliar as ações subversivas e de oposição como anarquistas, o professor julga a crítica ao governo como algo negativo, que poderia trazer prejuízos aos alunos se enveredassem por esse caminho. Para ele, a Educação seria o modo dos estudantes atingirem melhores condições de vida, o que significava garantir a possibilidade de trabalhar, construir uma família e consumir de forma pacífica.

Luíz tinha verdadeiro interesse pelo bem-estar de seus alunos, acreditava que seu compromisso como educador ia além de prover a formação acadêmica deles. Após narrar situações em que visitou em casa alguns estudantes que demonstraram dificuldades de comportamento ou aprendizado, conclui: "o professor tem que saber todo problema do aluno, ele resolve muitos problemas psicológicos". Com essa consideração, o entrevistado manifesta sua compreensão heroica e romântica do papel do educador, como aquele que interfere também no contexto social e familiar de seus alunos para orientar nos dramas e conflitos por eles enfrentados.

Em seguida, o professor foi questionado sobre as greves e mobilizações que ocorreram durante o período da ditadura militar. Nesse momento sua memória apresenta uma contradição: "naquela época não havia greve", mais adiante ele corrige: "teve muita greve". Sobre sua participação nesses movimentos ele repete enfaticamente: "Nunca, nunca, nunca [...] até no meu armário eu pus uma placa: Nunca mais vou fazer greve". Luíz explica sua posição inativa, usando como argumento a pouca eficácia dos protestos. Bosi (1994) esclarece que o papel do velho na sociedade é alertar as novas gerações sobre as falhas cometidas no passado para que não se repitam. Assim, o entrevistado adverte os jovens pesquisadores e futuros professores sobre o idealismo dos moços, que se enganam com a possibilidade de mudar o sistema: "esse problema preocupa mais a juventude [...] a pessoa idosa passou por tanto, que no fim [...] tudo a mesma coisa" [...] "muito jovem que aparece nesses comícios são iludidos". Em sua longa existência ele demonstra um pensamento distópico, considerando pouco o progresso que se obteve com tais militâncias. 
Durante o regime militar, o arrocho salarial a que foram submetidos os professores, aliado à expansão das escolas públicas de $1^{\circ}$ e $2^{\circ}$ graus, levou a categoria a transformar as suas associações profissionais, até então de caráter marcadamente recreativo, em verdadeiros sindicatos que passaram a formular e organizar a luta por melhores condições de vida e de trabalho. A maior expressão desse fenômeno foi às greves de milhares e milhares de professores, a partir do fim da década de 1970, em quase todos os estados do país. Esse tipo de movimento, pelo seu ineditismo à época, chamou a atenção da sociedade que, a despeito de guardar da profissão uma imagem associada à abnegação e ao sacerdócio, apoiou as suas mobilizações (FERREIRA JUNIOR; BITTAR, 2006, p. 1175).

O abalo psicológico causado pela opressão da ditadura é ainda tão presente na vida do entrevistado que ele nega ter tido conhecimento sobre atividades subversivas e contato com pessoas envolvidas: "eu não tinha amizade com eles". É perceptível que ele não quer falar sobre o assunto, justificando seu procedimento despolitizado com a faixa etária das crianças com quem trabalhava: [...] "o primário era mais acomodado" [...] "era muito difícil professor primário mexer com essas coisas". Essa postura vai ao encontro das conclusões de Thompson (2002, p. 359) que afirma que "as histórias de vida articulam os significados da experiência e sugerem maneiras de enfrentar a vida". Assim, o professor encontra diferentes formas de explicar os acontecimentos, suas escolhas e atitudes.

Lira (2010) comenta que os professores sofreram no mínimo dois tipos de repressões. A primeira de caráter ideológico, já que não Ihes permitiam ter liberdade em sala de aula e a outra, financeira, pois os salários foram reduzidos e a verba destinada para a Educação diminuiu. Ao invés de participar dos movimentos grevistas reivindicando melhores salários, o professor Luíz buscou na jornada dupla o meio de sustentar sua família. Trabalhava na escola e como atendente em um hospital, percorrendo grandes distâncias. As atividades escolares tinham que ser realizadas aos finais de semana: "No domingo que eu planejava, e fazia correção dos cadernos, tudo no domingo". Em contrapartida ele avalia o professor como alguém reconhecido, desconsiderando os baixos salários e a 
opressão do sistema: "o profissional de antigamente era de família". Mais uma vez o discurso é incoerente, pois a consideração pelo profissional deveria vir do empregador, porém ele não faz essa análise, prefere apontar os valores tradicionais da época como critério para julgar como o professor era visto.

Percebe-se que ao ser questionado sobre esses assuntos, o entrevistado entende que a sociedade atual espera um comportamento militante, e provavelmente ele se sinta constrangido em revelar que não foi ativista. Deste modo, busca argumentos para se desculpar. Essa iniciativa é identificada por Bosi (1994, p. 63) nos discursos do idoso: "a "pressão dos preconceitos" [...] pode modelar seu passado e, na verdade, recompor sua biografia individual".

Observa-se, também, em seus relatos o clima de apreensão e medo que dominava a época com relação às torturas e os desaparecimentos: "quantos foram presos [...] muitos foram presos", em outro momento ele afirma "a gente sempre ficava preocupado". Isso demonstra que não desconhecia os fatos violentos praticados pelo governo e estas circunstâncias o faziam viver em contínua inquietação e temor por sua família, adaptando-se ao regime como forma de evitar penalidades. $O$ fato de que até os dias atuais ele não faz críticas abertas ao sistema comprova que ainda não se sente seguro para falar com liberdade.

Santos (2000, p. 6) afirma que "os depoimentos permitem acesso a uma realidade demarcada pelas vivências de cada entrevistado" e essa experiência de vida, submetida à coerção e o temor, é ressaltada nas narrativas do professor Luíz. Calar essas lembranças, no entanto, não é a melhor escolha. As memórias dolorosas quando são suprimidas podem causar transtornos psicológicos graves, como a ansiedade e a depressão. Falar sobre essas recordações é essencial para a recuperação emocional dos depoentes, permitindo que estas sejam reorganizadas e as feridas cicatrizem. Essa possibilidade de expressar suas vivências, portanto, pode ser libertadora para os idosos. 


\section{Adventismo e Ditadura}

Outro aspecto que se destaca em diversos momentos do depoimento do professor Luíz são as referências a sua profissão de fé: "a gente como adventista sabe controlar a posição, se nós cremos que a autoridade é instituída por Deus, Deus sabe por que ele pôs aquela autoridade lá", e é dessa forma que ele avalia o que foi o governo militar no país. Ao fazer referência ao texto bíblico de Romanos 13.1-2, que diz: "Cada qual seja submisso às autoridades constituídas [...] aquele que resiste à autoridade, opõe-se à ordem estabelecida por Deus", o entrevistado explica o período histórico da ditadura no Brasil como sendo um determinismo divino, o qual não se pode contestar.

A IASD foi organizada nos Estados Unidos, em 1863, e há evidências históricas de que, em 1895, já existiam três igrejas no Brasil (TIMM, 2005). Entre os fundadores da IASD está Ellen Gould White (1827-1915) reconhecida como profetisa pelos membros da igreja, tendo recebido aproximadamente dois mil sonhos e visões ao longo de sua vida, escrevendo 55 mil páginas, tornando-se a autora feminina mais traduzida da atualidade. Seus escritos que trabalham sobre temas como educação, família, saúde, profecias, criacionismo, origem da vida e cultura, servem de orientação para a igreja e muitos de seus conselhos têm sido considerados, atualmente, como válidos por diversos segmentos científicos. É com base nos textos da autora que o entrevistado defende suas posições: "a irmã White fala que nós não devemos pertencer a sindicatos", afirma7.

Contudo, ainda que a diretriz institucional da IASD fosse de manterse afastada das questões políticas, informalmente seus líderes manifestavam apoio ao regime como forma de garantir sua liberdade de atuação no país. Segundo o pastor adventista Dr. Ebling (2014)

\footnotetext{
7 Entre outras citações, White orienta: "Não nos devemos nos associar a sindicatos trabalhistas. Devemos permanecer livres perante Deus". WHITE (1985, p. 115).

$8 \mathrm{Pr}$. Dr. José Carlos Ebling em entrevista concedida à orientadora da pesquisa, Prof. a Janaina Silva Xavier, em 20 de maio de 2014, no Centro Universitário Adventista de São Paulo, Engenheiro Coelho.
} 
Na época a Igreja Adventista no Brasil, tomou uma posição não oficial porque a Igreja Adventista nunca se oficializou com uma posição política, é uma das regras do manual da igreja, que os regulamentos denominacionais não se envolvessem politicamente [...] dessa forma a Igreja Adventista se calava, não falava nada oficialmente, mas extra oficialmente era simpática às forças armadas, militarismo, a Ditadura Militar, sempre louvando, defendendo, defendendo não, elogiando, aqueles que tiveram a coragem de defender o Brasil para que não caísse nas garras do mal do comunismo.

De acordo com Mattos (2014), a posição de não se envolver publicamente com assuntos políticos não foi uma exclusividade dos adventistas. Segundo o autor, os missionários protestantes, vindos para o Brasil, do sul dos Estados Unidos - presbiterianos, metodistas e batistas trouxeram a experiência da derrota na Guerra Civil Norte Americana (18611865) que os fizeram adotar essa postura apolítica.

A concepção escatológica que a Igreja Adventista tem sobre o mundo influencia diretamente a forma de pensamento e o modo como seus membros encaram as questões sociais. Ao vermos o testemunho do professor Luíz percebe-se que ele procurava não opinar sobre a situação política do país, queria apenas cumprir o seu trabalho da melhor maneira possível.

Bosi (1994) apresenta que na memória política o idoso não permanece neutro, pelo contrário, ele quer fazer julgamentos, marcando o lado que estava quando o fato ocorreu. Ela afirma, também, que a localização de classe do sujeito e sua profissão têm significativa importância na compreensão dos acontecimentos. No caso do entrevistado, sua atuação como professor pressupõe uma posição mais crítica e contrária ao regime, porém, por ter passado pela conversão religiosa, em 1957, sua visão e seus discursos foram profundamente afetados, fazendo com que ajustasse sua fala, e seus pensamentos, a vontade divina.

Deste modo, o professor, que demonstra um significativo conhecimento da História Universal, avalia a trajetória humana a partir de suas conviç̧ões religiosas: "a gente como estuda a palavra de Deus, a gente vê que a história é essa, a história está se desenrolando para o final da história". Essa cosmovisão escatológica foi o principal argumento 
utilizado pela IASD para explicar o regime militar entre outras tragédias mundiais. A revista de variedades Atalaia, que circulava no meio adventista brasileiro, a partir da década de 1960, apresentava em seus artigos análises sobre o momento político em que o Brasil se encontrava. Esses textos vão ao encontro dos discursos do entrevistado:

O mundo está perplexo social, política e religiosamente. Confusão, temor, incerteza, inquietação, intranquilidade, desassossego, apreensão - eis as características de nossos dias, os sinais notáveis dessa época afetam a todas as nações da Terra. Para o mundo atual não existe outra esperança além da milenária esperança da igreja a bemaventurada esperança do retorno do nosso Senhor (REVISTA ATALAIA, 1966, p. 4 - 5).

Diante de tal quadro, o periódico defendia a separação dos poderes:

[...] a Igreja deve viver separada do Estado. A união dos dois poderes seria fatal para um ou para o outro, ou mesmo para ambos, igualmente. Ou a Igreja ficaria desvirtuada de sua missão, com a esfera de atividade cerceada, ou o Estado se tornaria um joguete nas mãos dos guias espirituais, impossibilitando de se dirigir, de se governar a si mesmo (REVISTA ATALAIA, 1967, p. 13).

Percebe-se, portanto, na fala do professor, a presença de um "discurso oficial" a que se refere Pollock (1989) como sendo um comportamento em relação ao passado ligado à necessidade de encontrar um modus vivendi e a ocultar possíveis sentimentos de culpa pela falta de comprometimento e colaboração com a sociedade de sua época. Pollock (1989) salienta, ainda, que essas narrativas servem para reforçar noções de pertencimento a determinadas coletividades e manter a coesão dos grupos. No caso do entrevistado, sua disposição é a de salvaguardar a postura da IASD com quem mantém fortes laços identitários.

Portelli (2006, p. 108), por sua vez, afirma que por serem as memórias traumáticas "incontáveis", os narradores se apoiam em estruturas mediadoras, entre elas, a religião, para descreverem as palavras e as ideologias que representam. Ou seja, o professor silencia suas memórias individuais e formaliza uma narrativa coerente e estruturada baseada na posição oficial da IASD. É desse modo, segundo o autor, que o 
"indizível é dito". Pollock (1989, p. 6) acrescenta, ainda, que "a memória especificamente política pode ser motivo de disputa entre várias organizações". Este conflito de memória é o que se evidencia nas narrativas do entrevistado.

Ainda em seu depoimento o professor revela outra atitude comum aos adventistas da época. Em sala de aula ele se manifestava: "contra o álcool, contra o fumo né, falava mesmo". Esse comportamento também foi aconselhado por White (1993, p. 384) ao escrever: "Mesmo não sendo sábio nos envolvermos em questões políticas, ainda assim é nosso privilégio tomar uma posição decidida sobre todas as questões relacionadas à reforma da temperança". Esse ativismo manifestado em ações de saúde e assistência social foi à forma que a IASD encontrou para contribuir com as mazelas da sociedade e os membros da igreja se envolveram intensamente nessas atividades, como se pode apreender na fala do professor.

Vê-se, portanto, o quanto a fé e o pertencimento a IASD foram fatores determinantes para direcionar a compreensão e o comportamento do professor Luíz naqueles dias e, ainda na atualidade, servem como elemento de coesão de suas memórias.

\section{Considerações Finais}

Ao chegarmos ao final deste texto nota-se a relevância do tema para a compreensão da Educação brasileira atual, sendo necessário conhecer não só sua História, mas, também, seus desdobramentos no cotidiano das salas de aula. Ao focar nos anos do golpe militar, percebe-se que a Educação passou por alterações significativas, em que a legislação brasileira unificou os estabelecimentos de ensino, determinando a criação de um currículo comum e obrigatório, onde o ensino crítico e tradicional foi substituído por uma pedagogia técnica e profissionalizante, com o claro objetivo de desenvolver a produtividade industrial e, dessa forma, impulsionar a economia brasileira. Contudo, é importante frisar que as disciplinas de História e Geografia não foram excluídas totalmente, mas tiveram sua carga horária reduzida e seus conteúdos limitados. 
Sobre a problemática proposta nessa pesquisa, verifica-se que o entrevistado, já idoso, relembra sua prática pedagógica condizente com o que os estudiosos do período apresentam em suas pesquisas. A forma como ministrava os conteúdos e se adequava ao sistema e seu quadro narrativo, que apresenta a omissão na participação em greves e sindicatos, e o temor à repressão e à tortura que comumente são ligadas à ditadura militar, se deve a sua condição de cidadão comum, trabalhador e cristão. Seus depoimentos demonstram que no conflito entre o individual e o coletivo, a segurança da família, a manutenção do trabalho estável e os valores de sua cosmovisão religiosa foram mais importantes que enfrentar as demandas de ordem social e, dessa forma, é possível entender que os professores também viviam num clima de insegurança, constrangimento, tolhidos em suas manifestações, não obstante, cada qual reagia da maneira condizente à sua visão de mundo.

Durante a coleta dos depoimentos, constata-se que a memória é produzida a partir das interações do narrador com os indivíduos ao seu redor, suas narrativas são uma revelação das complexas relações que o depoente fez ao longo da vida. Em alguns momentos da entrevista ocorre a ocultação de determinados fatos, distanciamentos e aproximações das ideologias deste professor com a percepção de outros docentes e daquilo que é encontrado em grande parte dos livros e documentos sobre o período ditatorial.

A partir de todas essas considerações, conclui-se que a maior contribuição das narrativas orais sobre a ditadura militar talvez não seja levantar novos fatos sobre o tema, mas perceber como as pessoas se sentiam, suas tensões, dilemas, vivências, conflitos, expectativas e sonhos. No caso do professor Luíz, sua experiência interferiu, também, na transmissão de suas memórias para além da História militar, pois ele considera mais importante para a vida dos futuros docentes compreenderem seu papel na sociedade e a relevância de um ensino prático baseado nos valores morais bíblicos. Ao permitir que ele expressasse seu conhecimento, essa pesquisa significou deixá-lo continuar cumprindo seu papel de professor. 


\section{Referências}

BOSI, Ecléa. Memória e sociedade: memória dos velhos. 13. ed. São Paulo: Companhia das Letras, 1994.

LOURO, Guacira Lopes. Mulheres na sala de aula. In: DEL PRIORE, Mary; PINSKY, Carla Bassanezi (org.). História das mulheres no Brasil. 10. ed. São Paulo: Contexto, 2015.

FERREIRA JUNIOR, Amarilio; BITTAR, Marisa. A ditadura militar e a proletarização dos professores. Caderno Cedes, Campinas, v. 27, n. 97, p. 1159-1179, set./dez. 2006. Disponível em:

http://www.scielo.br/pdf/es/v27n97/a05v2797.pdf. Acesso em: 1 mar. 2017.

FONSECA, Thais Nívia de Lima. O ensino de história do Brasil: concepções e apropriações do conhecimento histórico (1971-1980). In: CERRI, Luis Fernando (org). O ensino de história e a ditadura militar. 2. ed. Curitiba: Aos Quatro Ventos, 2007. p. 35-54.

LIRA, Alexandre Tavares do Nascimento. A legislação de educação no Brasil durante a ditadura militar (1964-1985): um espaço de disputas. 2010. Tese (Doutorado em história social) - Instituto de Ciências Humanas e Filosofia, Universidade Federal Fluminense, Niterói, 2010.

MATTOS, Paulo Ayres. Um bispo na luta popular. In: DIAS, Zwinglio Mota (org.) Memórias ecumênicas protestantes: os protestantes e a ditadura: colaboração e resistência. Parceria: Rio de Janeiro, 2014. p. 117-125.

PLAZZA, Rosimary; PRIORI, Angelo. O ensino de história durante a ditadura militar. 2008. Disponível em:

http://www.diaadiaeducacao.pr.gov.br/portals/pde/arquivos/956-4.pdf . Acesso em: 1 set. 2017.

POLLOCK, Jackson. Memória, esquecimento, silêncio. Revista Estudos Históricos, Rio de Janeiro, v. 2, n. 3, p. 3-15,1989.

POLLAK, Michael. Memória e identidade social. Revista Estudos Históricos, Rio de Janeiro, v. 5, n. 10, p. 200-212,1992.

PORTELLI, Alessandro. O massacre de Civitella Val di Chiana (Toscana, 29 de junho de 1944): mito e política, luto e senso comum. In: FERREIRA, Marieta de Moraes; AMADO, Janaína (org.). Usos \& abusos da história oral. 8. ed. Rio de Janeiro: Editora FGV, 2006. p. 103-130.

PRADO, Eliane Mimesse. A disciplina história nos anos da ditadura militar. Jundiaí: Paço Editorial, 2014.

REVISTA ATALAIA, Tatuí, SP, Jan. 1967. 
REVISTA ATALAIA. Tatuí, SP, jul. 1966.

SANTOS, Antônio César de Almeida. Fontes orais: testemunhos, trajetórias de vida e história. Revista Via Atlântica, São Paulo, n. 4, p.1-10, 2000.

SAVIANI, Demerval. História das ideias pedagógicas no Brasil. Campinas: Autores Associados, 2010.

THOMPSON, Alistair. Histórias (co) movedoras: história oral e estudos de migração. Revista Brasileira de História, São Paulo, v. 22, n. 44, p. 341364, 2002.

TIMM, Alberto Ronald. A Igreja Adventista de Campos dos Quevedos 19052005. Engenheiro Coelho, SP: Centro Universitário Adventista de São Paulo, 2005.

TOURTIER-BONAZZI, Chantal de. Arquivos: Propostas metodológicas. In: FERREIRA, Marieta de Moraes; AMADO, Janaína (org.). Usos \& abusos da história oral. 8. ed. Rio de Janeiro: Editora FGV, 2006. p. 233-246.

USP - Universidade de São Paulo. Instituto de Educação Caetano de Campos. Disponível em: http://www.imagens.usp.br. Acesso em: 19 out. 2017.

VEDANA, Léa Maria. A educação em SC nos anos 60. Revista Esboços, Florianópolis, v. 5, n. 5, p. 39-47, dez. 1997.

VOLDMAN, Danièle. Definições e usos. In: FERREIRA, Marieta de Moraes; AMADO, Janaína (org.). Usos \& abusos da história oral. 8. ed. Rio de Janeiro: Editora FGV, 2006. p. 33-42.

WHITE, Ellen. Obreiros evangélicos. Tatuí, SP: Casa Publicadora Brasileira, 1993.

WHITE, Ellen. Testemunhos seletos. Tatuí, SP: Casa Publicadora Brasileira, 1985. v. 3. 